Lingua 49 (1979) $51-70$

(C) North-Holland Publishing Company

\title{
TOWARD A RECONSTRUCTION OF THE BALTO-SLAVIC VERBAL SYSTEM
}

\author{
Frederik KORTLANDT \\ University of Letden, Dept. of Linguistics
}

Received June 1978

To the memory of Chr. Stang

0.

The reconstruction of Balto-Slavic must of necessity be based upon two types of data. On the one hand, it requires the application of the comparative method to the three branches of the sub-family (West Baltic, East Baltic, Slavic). One reason for writing this article is that, to my mind, especially the Slavic evidence has not adequately been evaluated. In particular, I think that the non-Bulgarian material must be taken into account to a larger extent. On the other hand, Balto-Slavic must be viewed as a further development of the Indo-European proto-language, the reconstruction of which is chiefly based on material from the early recorded history of its southern branches (Indo-Iranian, Greek, Hittite). As the history of Indo-European studies shows, the reconstruction of the protolanguage is likely to have a bias toward the language(s) on which it relies primarily. It is therefore of paramount importance to consider time and again the likelihood of the developments which are implied for the other branches (especially Celtic, Balto-Slavic, and Tocharian). ${ }^{1}$ Indeed, I think that a few details of the Indo-European verbal system can be clarified on the basis of the Baltic and Slavic evidence.

${ }^{1}$ We are now in a much better position for such an evaluation than a few years ago because a number of long-debated problems have recently been solved. Thus, the relation between absolute and conjunct verbal endings in Celtic has essentially been clarified by Cowgill (1975), and the relation between the $s$-subjunctive and the $a$-subjunctive by Rix (1977:153). These authors have finally given an explanation which accounts for the distribution of the respective categories. Our insight into the fate of the PIE ablaut system in Tocharian, which is a prerequisite for a correct understanding of the verbal system, has considerably increased as a result of Penney's discussion (1978). 


\section{Slavic ido (jado, bodo) and the PIE imperative}

The Slavic present tense suffix $-d e / o$ - contains PIE $* d h$, not $* d$, because the root vowel of $i d g$ would otherwise have become acute (cf. Winter 1978), which is incompatible with the Old Russian accentuation pattern idú, idešb (e.g., Stang 1957: 115). The suffix cannot be compared with the one in Lith. vérda 'boils', inf. virti, because the latter cannot be separated from the $d$ in causatives and iteratives and is probably not old (cf. Stang 1942: 143). Neither can it be compared with kladQ, kradQ, etc. because "le présent en -de- qu'on restitue ou qu'on peut supposer s'ajoute à une forme de la racine à voyelle longue, diphtongue ou groupe de voyelle plus $r, l$ : le présent jíde-, sur brève, semble étranger au type" (Vaillant 1966: 179). A comparison with Greek -thō or Latin $-d \bar{o}$ is even more hazardous.

The absence of $d$ in the infinitive and in some of the participles suggests that the paradigms of $i d Q$ and jado belong to a younger layer than those of $k l a d Q$ and $k r a d Q$, where the $d$ is an early Slavic innovation in view of Latvian klâju, krâju. It seems therefore reasonable to look for a flexional rather than a derivational origin of the suffix. I would suggest a connection with the PIE imperative suffix *-dhi, so that we can directly compare idi with Gr. $i$ thi and Skt. ihí. This reconstruction also explains the ablaut and accentuation patterns of the Slavic verb. ${ }^{2}$

The hypothesis advanced here is supported by several pieces of evidence. First of all, it may account for the particular aspectual behaviour of OCS iti (cf. Van Wijk 1927: 95). Another argument can be derived from the 3rd pl. form bode, for which Vaillant's reconstruction *-oint (1930: 246 and 1966: 16f) is "sowohl im Slawischen wie im Idg. ein Notbehelf" (Watkins 1969: 219). ${ }^{3}$ The ending $-Q$ dates apparently from a stage which was anterior to the substitution of the optative for the imperative. In athematic verb forms, the PIE secondary endings 1 st $s g .{ }^{*}-m$ and $3 \mathrm{rd} \mathrm{pl}$. ${ }^{*}$-nt became ${ }^{*} b$ after non-labiovelar consonants. ${ }^{4}$ The homophony of these endings with the last syllable of the imperative ${ }^{*} b d b$ can easily have

\footnotetext{
${ }^{2}$ The stress was regularly retracted to the root vowel in late Balto-Slavic (Kortlandt 1975a:5f) and shifted to the desinence in Ru. idi as a result of Dybo's law (ibidem, p. 14 and passim). The rise of the new paradigm must be dated between these two developments.

${ }^{3}$ I see no substantial difference between Mareš's point of view (1962: 30) and Vaillant's.

${ }^{4}$ The merger of these forms is a consequence of the fact that the fall of word-final * $t$ was anterior to the elimination of the syllabic resonants. The former development preceded Hirt's law, whereas the latter was posterior to it. The 3rd pl. ending $-e$ of the sigmatic aorist continues PIE *-ent.
} 
brought about the creation of a new thematic paradigm, the $3 \mathrm{rd}^{-} \mathrm{pl}$. ending of which has been preserved in bodo. The latter form survived because the 3 rd pl. ending of the optative *-iHnt (for PIE *-iHent) merged phonetically with the 3rd sg. ending *-iHt (for PIE *-ieHt). Similarly, the 3rd pl. form $b e$ replaces earlier ${ }^{*} b i$ in the conditional because the latter had become homophonous with the $3 \mathrm{rd} \mathrm{sg}$. form $b i$. I conclude that early Slavic possessed an imperative paradigm which looked something like this:

$\begin{array}{lllc} & \text { thematic } & \text { athematic } & \text { cf. Sanskrit } \\ \text { 2nd sg. } & \text { bere } & \text { idi } & \text { ihí } \\ \text { 3rd sg. } & \text { bere }(t) & \text { ei( }(t) & \text { étu } \\ \text { 2nd pl. } & \text { berete } & \text { ite } & \text { itá } \\ \text { 3rd pl. } & \text { beron }(t) & \text { jen }(t) & \text { yántu }\end{array}$

\section{Slavic xostto and the PIE optative}

The 2 nd sg. form which appears in Old Bulgarian texts as xosti represents an old optative, as was observed by Oblak (1893: 469f). ${ }^{5}$ It relates to the indicative xosteši as the $2 \mathrm{nd} \mathrm{pl}$. form which is attested in Ru. xotite and Sln. hotite relates to xoštete (cf. Vaillant 1966: 403). The existence of two flexional paradigms is corroborated by an analysis of the accentuation pattern. On the one hand, the mobility in Ru. xoču, xóčeš, which is also found in Serbo-Croat and Slovene, points to a paradigm with fixed stress on the root syllable before the operation of Dybo's law. ${ }^{6}$ On the other hand, the noninitial stress of Ru. xotite, xotjatt, which is also confirmed by the Serbo-Croatian and Slovenian evidence, points to an older type of accentual mobility, with retraction of the stress in the 1st sg. form (cf. Stang 1957: 109ff). This retraction is actually attested in the Freising Fragments (henceforth: FF), where we find choku (I 7) and chocu (III 48). These forms were stressed on the root syllable because a stressed ${ }^{*} \varphi$ is never reflected as $u$ and the double occurrence of the form excludes a scribal error (cf. Kortlandt 1975b: 408ff). For a full appreciation of these instances I give the original text with Žgur's German translation (1968):

I 7 Itebe bosirabe choku biti izpovueden uzeh moih / greh "Und dir, Diener Gottes, möchte ich alle meine Sünden bekennen".

${ }^{5}$ Cf. also Trubeckoj 1922: 19; Lekov 1934: 174; Vaillant 1966: 35 . I am unable to share Ramovš's view that the ending continues *-ei (1920: 129) for both semantic and chronological reasons.

${ }^{6}$ Cf. Kortlandt 1975a: 14 and passim. 
III 46 Caiuze / moih grehou Iradze / chocu caiati elicose / zimizla imam eche / me bose postedisi "Ich bereue meine Sünden und gern werde ich sie bereuen, wenn ich mir bewusst sein werde, dass $\mathrm{Du}$, o Gott, wirst Gnade walten lassen".

I conclude that the 1st sg. forms of the indicative and the optative were accentually distinct. Considering finally the secondary ending of the $3 \mathrm{rd} \mathrm{pl}$. form $b q d Q$, we arrive at the following tentative reconstruction: ${ }^{7}$

$\begin{array}{llll} & \text { indicative } & \text { optative } & \text { cf. Gothic } \\ \text { 1st sg. } & \text { xòtjo } & \text { xötjg } & \text { wiljau } \\ \text { 2nd sg. } & \text { xòtješs } & \text { xötji } & \text { wileis } \\ \text { 3rd sg. } & \text { xòtje } & \text { xötji } & \text { wili } \\ \text { 1st pl. } & \text { xòtjems } & \text { xotíms } & \text { wileima } \\ \text { 2nd pl. } & \text { xòtjete } & \text { xotíte } & \text { wileip } \\ \text { 3rd pl. } & \text { xòtętb } & \text { xoté } & \text { wileina }\end{array}$

Both the indicative and the optative continue the PIE athematic optative, which had $*_{-i e H-}$ in the singular and $*_{-i H-}$ in the plural. The singular forms received the normal thematic endings, which were also introduced in the 1st and $2 \mathrm{nd} \mathrm{pl}$. indicative forms in order to differentiate them from the optative. ${ }^{8}$ The $1 \mathrm{st}$ pl. optative ending ${ }^{*}-m z$ is attested in FF pomenem $z e$ (II 15) 'meminerimus' and ozstanem (II 17/18) 'omittamus'. The 3rd pl. form of the indicative survived because the optative had a different (secondary) ending.

\section{Slavic mogo vs. vědě and the PIE perfect}

The traditional view that the form védě, which is found in Old Bulgarian, Old Russian, Old Czech, and Old Slovene (FF), contains a medial ending (e.g., Vaillant 1966: 76) cannot be maintained. Both the meaning and the root vocalism point to its historical identity with Gr. oída and Skt. véda. The comparison with Latin vidi is fallacious because the latter is a preterit of the stem *ueid- 'see', while the other forms belong to the stem *uoid-

${ }^{7}$ The forms given here are posterior to the rise of the new timbre distinctions but anterior to Van Wijk's law: they belong to the stage between 13 and 14 in terms of Kortlandt 1975a: xii. For the root vocalism, which cannot be discussed here, see Vaillant 1966: 78.

${ }^{8}$ The latter analogical introduction may have been posterior to Dybo's law in view of the rising tone in SCr. hòcerno, hòcete. 
'know' and have present meaning (cf. Watkins 1969: 152). There is no trace of medial forms in Slavic and the ending of vědě requires an internal explanation. ${ }^{9}$

The second Slavic verb for which perfect origin is beyond doubt is moge, which relates to Gothic mag as věde relates to wait. The difference between the thematic flexion of mogg and the athematic flexion of verde calls for an explanation. I think that the essentially correct solution was found by Trubeckoj, who pointed out that the perfect was originally neutral with respect to the distinction between present and preterit and became subject to morphological differentiation when tense turned into an obligatory category (1922: 16). The same development occasioned the creation of Gothic mahta. When word-final *t was lost in Balto-Slavic, the secondary thematic ending of the $3 \mathrm{rd}$ sg. person *-et merged with the perfect ending $*_{-}$. Since the plural forms of the perfect had received the normal (unmarked) secondary endings at an early stage, the enlargement of $1 \mathrm{st} \mathrm{sg}$. *-a to *-am and the replacement of $2 \mathrm{nd} \mathrm{sg.}{ }^{*}$-ta with $*_{\text {-es }}$ are natural developments.

Van Wijk established the presence of a historical connection between verbs of the type gorjo, gorěti, Lith. gariù, garëti, and the PIE perfect (1929: 238f and 1933: 138f). I think that the singular and 3rd pl. perfect endings received an additional $*_{-i} i$ from the primary athematic endings when the form had a definite present meaning. ${ }^{10}$ This hypothesis accounts both for védě, which probably had a PIE preterit *ueideH- in view of Gr. $\bar{e} e i d \bar{e}$, and for the $i$-flexion of such verbs as goréti. The innovation was possibly evoked by the merger of the $3 \mathrm{rd} \mathrm{sg}$. ending $*_{-} e$ with the secondary thematic ending as a result of the loss of word-final $* t$, just as may have been the case with the Greek 3rd sg. thematic ending -ei. If this line of thought is correct, we can postulate the following paradigms for a certain stage of Proto-Slavic: ${ }^{11}$

${ }^{9} \mathrm{I}$ am inclined to the view that the $a i$-medium was a dialectal Indo-European innovation (cf. Meillet 1922: 68).

${ }^{10}$ The enlargement of the perfect endings by an element $-i$ was suggested by Kurytowicz, who still speaks of a "replacement of the active by the mediopassive" (1964: 81). I cannot share his view (repeated by Watkins 1969: 222) that *-ei yielded $-i$ in Lithuanian. Kuryłowicz's objections against the comparison of Lith. mini, minèjo with Gr. mainetai, emáne (1964: 79f) are refuted by Schmid (1963: 79ff), though the latter's laryngealist reinterpretation of Hirt's $-\bar{e} i / i$-ablaut cannot be upheld. I intend to treat the origin of the $i$-flexion in detail on another occasion.

${ }^{11}$ The stage of development reconstructed here is posterior to the merger of $a, \bar{a}$ with $o, \dot{\bar{o}}$ and the rise of nasal vowels, but anterior to the palatalizations, the monophthongization of diphthongs, and the rise of the falling intonation. 


$\begin{array}{lllc} & \text { neutral } & \text { present } & \text { cf. Sanskrit } \\ \text { 1st sg. } & \text { màgq } & \text { waídai } & \text { véda } \\ \text { 2nd sg. } & \text { màges } & \text { waístai } & \text { véttha } \\ \text { 3rd sg. } & \text { màge } & \text { waídei } & \text { véda } \\ \text { 1st pl. } & \text { magmè } & \text { waidmè } & \text { vidmá } \\ \text { 2nd pl. } & \text { maktè } & \text { waistè } & \text { vidá } \\ \text { 3rd pl. } & \text { magé } & \text { waideti } & \text { vidúr }\end{array}$

The paradigms of moge and védě were subsequently assimilated to those of bero and damb, respectively, while the paradigm of gorět $i$ merged with other types of $i$-flexion. It is remarkable that all verbs in -ét $t i$ with $o$ vocalism in the root have a stem-final resonant, except xotěti: goréti, polěti, bolěti, gověti, bojati sę, stojati. All surviving athematic verbs in Slavic have a stem in a dental obstruent, with the exception of imamb.

\section{The 1st sg. ending}

The PIE primary endings *-mi and *-oH have been preserved in Slavic $-m b$ and Lith. $-\dot{u}$ (Latv. $-u$ ), respectively. The secondary thematic ending *-om became *-um in early Balto-Slavic (cf. Kortlandt 1978b). It is reflected as $-z$ in Slavic, where it spread to the sigmatic aorist. In Prussian we find $-a$ for PIE ${ }^{*}-o H$, as Stang pointed out a long time ago (1942: 225). ${ }^{12} \mathrm{I}$ think that Schmid's explanation of the athematic ending in this language (1969) is essentially correct: PIE *-mi was replaced with $*_{-m o H}$ (asmu), later also ${ }^{*}$-moHi (asmai), in the same way as the 2 nd sg. ending ${ }^{*}$-si was replaced with *-seHi (assei). The form asmau $(29,3)$ is likely to be a printer's error. The East Baltic athematic ending, Lith. -mi, most probably received its acute intonation from the 2 nd sg. ending after the monophthongization of *ei (cf. Vaillant 1966: 8; Schmid 1969: 360) and should be separated from the Prussian ending.

According to the prevailing view, the Slavic ending $-Q$ continues the PIE thematic ending $*_{-o} H$, enlarged by the secondary ending $*_{-} m .^{13}$

12 This point of view is repeated by Schmid (1963:12) and Vaillant (1966: 8), who leave out the crucial argument, viz. the impossibility of crixtia $(79,18)$ representing a 3 rd sg. form. Such remarks as "Richtiges vermutet schon bei Chr. S. Stang" (Schmid 1963: 8, fn. 36) and "so dass man die altpreussische Lautlehre um eine neue Auslautregel: idg. $-\bar{o}>-a$ vermehren kann" (ibidem, conclusion on p. 12) do not do justice to the great Norwegian linguist.

${ }^{13} \mathrm{Cf}$. Thurneysen 1884: 270; Meillet 1908: 412; Van Wijk 1916: 115; Lekov 1934: 29ff; Stang 1942: 213f; Kuznecov 1961: 89ff. 
There are several difficulties connected with this hypothesis. If the supplementary ${ }^{*}-m$ was added before the merger of ${ }^{*} \bar{a}$ and ${ }^{*} \bar{o}$, we would expect to find $-y$, as in kamy, Gr. ákmōn. The merger of * $\bar{a}$ and $* \vec{o}$ must be dated to approximately the same stage as the loss of the final nasal in the secondary ending *-um, while the latter development cannot have preceded the analogical spread of $*-m$. Moreover, the addition of $* m$ to the primary ending $*_{-o H}(*-a H)$ would have yielded a unique word-final cluster because wordfinal laryngeals were preserved up to a later stage (cf. Kortlandt 1975a: 29) and the acc. sg. ending ${ }^{*}-a H m$ had become ${ }^{*}-\bar{a} m$ before the loss of the syllabic resonants in Balto-Slavic, as the absence of de Saussure's law in Lith. rañka suggests. Finally, one fails to see the motivation for an enlargement of the primary thematic ending $*_{-} o H$ by the secondary athematic ending *-m. The inconsistencies can be eliminated if the decline of the PIE perfect is taken into account. As was pointed out above, the ending *-a was enlarged to ${ }^{*}$-am because the $3 \mathrm{rd}$ sg. endings ${ }^{*}-e$ and ${ }^{*}$-et merged when final * $t$ was lost in Balto-Slavic and the plural forms of the perfect had secondary endings. When $*^{*} a$ and ${ }^{*} o$ merged and a new preterit ${ }^{*} m a \dot{g} u$ next to the present $*$ màg $a$ was formed, the nasal ending replaced the reflex of PIE *-oH in the ordinary thematic flexion, perhaps in connection with the homophony of the latter with the preterit tense suffix $*_{-a H}$-.

\section{The 2nd sg. ending}

The Lithuanian ending $-i$ continues the PIE thematic ending $*_{-e H}$, which is still perceived in Greek and Celtic but has disappeared elsewhere. ${ }^{14}$ The Old Irish forms biri and -bir must be derived from *berei-s and *berei, respectively. ${ }^{15}$ The PIE secondary ending *-es regularly yielded -e in Slavic.

${ }^{14}$ Cf. Brugmann 1904; Meillet 1908; Van Wijk 1916; Lekov 1934: 54ff; Stang 1942: 225ff; Vaillant 1966: 9f.

${ }^{15}$ Cowgill's objection that " the postulated change of $*_{-}-e i$ to $*_{-i}$ requires an ad hoc exception to the general change of $\mathrm{IE} * e i$ to Celtic * $\bar{e}$ " $(1975: 51)$ is refuted by his own "rule by which Proto-Celtic *-oi and *-ai became Insular Celtic *-i " (p. 57, fn. 13). Gaulish -e is irrelevant because it reflects $*_{-}-e i e i$, not $*_{-} e i$, and because it is not Insular Celtic. I agree with Cowgill that -bir can phonetically be derived from *bheresi, as Meillet pointed out already (1908: 413). The point is that this reconstruction leaves the $2 \mathrm{nd} \mathrm{sg.} \mathrm{ending} \mathrm{of} \mathrm{the} \mathrm{present} \mathrm{classes}$ AI, AII, AIII (cii), BII, BIV unexplained (cf. Cowgill 1975: 61). I think that the original endings *-assi and *-isi were replaced with *-āse $i$ and ${ }^{*}-i s e i$ in exactly the same way as in Prussian and Slavic. The attested forms regularly developed as a result of the following chain of events: (1) rise of $* h$ from PIE $* s,(2)$ loss of $* h$ between posttonic vowels, (3) monophthongization of posttonic ${ }^{*} e i\left({ }^{*} a i,{ }^{*} o i\right)$ to ${ }^{*} i,(4)$ shortening of long final vowels, (5) vowel raising 
An analysis of the athematic ending must start from the four different reflexes which are found in the oldest Slavic texts, the Freising Fragments (FF) and the Kiev Leaflets (KL):

$-s i$ in FF iezi (III 68), KL esi (12x).

-sb in FF vuez (I 20), KL podasb (III 7).

$-s ̌ i$ in FF postedisi (III 50), KL veseliši (Ib 5), sztvoriši (III 5).

$-\varsigma$ s in FF zadenes (I 26), vzovues (I 32), prides (III 56/57).

Though the material is very limited, it shows a clear distribution: - si in the a copula, $-s b$ in the other athematic verbs, $-s i$ in the $i$-flexion (Leskien's class IV), and $-\check{s} b$ in the $e$-flexion (Leskien's classes I and II). There is no example of Leskien's class III verbs. The antiquity of the distribution is supported by the Old Prussian material, where we find $-s i$ for Slavic $-s ̌ b$ and -sei $(-s a i,-s e)$ for the other endings. Final $i$ was preserved in giwassi $(25,3$ and 65,29$)$ because it was stressed (cf. Kortlandt 1974: 301). ${ }^{16}$ The East Baltic athematic ending, Lith. -si, can be identified with Prussian -sei as *-seHi. Old Bulgarian generalized $-s i$ in the athematic verbs and $-s i$ elsewhere. The other Slavic languages substituted $-\check{s}$ for $-s ̌ i$ in the $i$-flexion, but preserved $-s i$ in the copula. The latter ending spread to the other athematic verbs in East Slavic and was lost in Polish.

We can now confidently assume that the replacement of PIE *esi with *eseHi was a Balto-Slavic innovation. As Van Wijk pointed out already (1916: 111f), the motivation for the analogical change must be sought in the PIE reduction of ${ }^{*}-s s-$ to ${ }^{*}-s$-, cf. Skt. ási, Gr. ei . ${ }^{17}$ The new ending spread to the $i$-flexion in all three branches of Balto-Slavic and to the athematic root verbs in the Baltic languages (cf. Stang 1966: 409). The thematic ending ${ }^{*}-e H i$ was replaced with ${ }^{*}$-esi in Prussian and Slavic in the same way as $1 \mathrm{st} \mathrm{sg} .{ }^{*}$-aH from ${ }^{*}-o H$ was replaced with ${ }^{*}$-am in the latter

and lowering, (6) loss of $* h$, (7) loss of short final vowels, (8) shortening of long vowels in final syllables (cf. also Boling 1972: 99ff). This chronology accounts for the genesis of 2nd sg. -renai and dat. sg. tuil (Cowgill 1975: 57, fn. 13). The ad hoc hypothesis of levelled absolute forms is not warranted.

${ }^{16}$ If we leave the copula out of consideration, the probability that the FF and KL endings have an identical distribution but no common origin is $3 \%$. If we leave the copula and verbs with derivative suffixes out of consideration in the Enchiridion, the probability that the distribution of $6 \times-s e i(-s e)$ after a monosyllabic verb root (waid-, ei-, dā-, stā-) and $3 \times-s i$ after the thematic vowel is accidental is $1.5 \%$. The probability that the agreement between Prussian and Slavic is due to chance is $0.05 \%$.

${ }^{17}$ As a result of this reduction, the paradigm received an aberrant stress pattern in late Balto-Slavic, cf. Kortlandt 1975a: 5f. The normal accentuation was restored after the introduction of the new ending. 
language. As the Slavic $\check{s}$ shows, the substitution must be viewed in connection with the decline of the athematic flexion, e.g. Ru. derëš', ližeš', replacing earlier *derši, *leikši, Vedic dárși, *rékși (cf. 3rd sg. rédhi).

\section{The 3rd sg. ending}

All attempts at deriving the three Slavic present endings $-t b,-t z$, and $-\emptyset$ from one another have failed. The first ending is dominant in Old Russian, the second in Old Bulgarian, and the third in most other languages. The only vestige of $-t$ in Serbo-Croat, Czech, Slovak, and Polish is the form jest next to je. In the Freising Fragments we find iezt (I 35), iest (II 64), gest (II 75,90) next to ie $(3 \times$ in I), ge $(5 \times$ in II), vzedli (II 62/63), dozstoi (II 95), and the form jest disappears in Slovene in the 15th century (Vaillant 1966: 25). The rising tone on the thematic vowel in Čakavian (Vrgada) rēstẽ ' grows' etc. (Jurišić 1966: 89) betrays a lost ending with a jer. The same holds for the long vowel in Slovak nesie etc. (cf. Stang 1952b).

Old Bulgarian instances of $-t b$ and $-\emptyset$ are relatively scarce. In the Assemanianus, where the ending $-t b$ is more frequent than in the other manuscripts, 25 out of the 34 forms in $-t b$ are athematic (Wiedemann 1886: 11). This suggests that the ending originally belongs to the athematic flexion (cf. Van Wijk 1931: 214). The ending $-\emptyset$ is particularly frequent in the Suprasliensis, especially in the $e$-flexion (examples of the $i$-flexion are rare). This must certainly be ascribed to the dialectal origin of the manuscript. Since the verbal system of the Suprasliensis is archaic in some respects (e.g., the preservation of věde and xošti, for which the glagolitic texts have věmb and xošteši $i$, there is no reason to regard the ending - $\emptyset$ as a secondary development. Moreover, such a hypothesis does not account for the distribution of the ending. A final judgment requires an evaluation of the modern dialectal evidence. From the point of view of the 3rd sg. and pl. endings, the Bulgarian and Macedonian dialects can be divided into four groups (cf. Lekov 1934: 109):

$\begin{array}{lllll} & \text { B1 } & \text { B2 } & \text { B3 } & \text { B4 } \\ \text { 3rd sg. } & -\emptyset & -\emptyset & -t & -(t) \\ \text { 3rd p1. } & -t & -\emptyset & -t & -(t)\end{array}$

The East Macedonian and the majority of the Bulgarian dialects belong to B1. The South Macedonian (e.g., Kostur) and a part of the West 
Bulgarian dialects belong to $\mathrm{B} 2$. The Macedonian dialects to the west of the line Tetovo-Bitola belong to B3, and a few isolated dialects in Kosovo Polje to B4. The ending $-t$ is optional in the latter dialects, which are apparently transitional between B3 and Serbian (which agrees with B2). This state of things suggests that the East Bulgarian dialects represent a further development of the language of the Suprasliensis, while the system of the oldest glagolitic texts has been preserved in the Ohrid area.

Now we turn to the East Slavic evidence. With respect to the presence or absence of a dental stop, we can distinguish six groups of Russian dialects (cf. Kuznecov 1960: 107ff; Panzer 1967: 291):

$\begin{array}{lllllll} & \text { R1 } & \text { R2 } & \text { R3 } & \text { R4 } & \text { R5 } & \text { R6 } \\ \text { 3rd sg. }-e- & -\mathrm{T} & -\mathrm{T} / \emptyset & -\emptyset & -\emptyset & -\emptyset & -\emptyset \\ \text { 3rd sg. }-i- & -\mathrm{T} & -\mathrm{T} & -\mathrm{T} & -\mathrm{T} & -\emptyset & -\emptyset \\ \text { 3rd pl. }-u- & -\mathrm{T} & -\mathrm{T} & -\mathrm{T} & -\mathrm{T} & -\mathrm{T} & -\emptyset \\ \text { 3rd pl. }-a- & -\mathrm{T} & -\mathrm{T} & -\mathrm{T} & -\emptyset & -\emptyset & -\emptyset\end{array}$

The $R 2$ ending $-T / \emptyset$ stands for: $-T$ if the preceding vowel is stressed and $-\emptyset$ if it is unstressed. Most dialects admit an alternative nonzero ending instead of $-\emptyset$, so that one could read $-(T)$ for $-\emptyset$. The systems of R2 and R4 are probably archaic because they are not easily explained in terms of analogical development. The antiquity of the zero ending is confirmed by the Novgorod birch bark documents, where we find ede (10), veze (10), ide (18), bude (18 and 19), xoce (19), pride (43), povede (53), čelomb běje (97) next to dastb (5), vzdastb (9), pridetb (40). It is also frequent in the Nestor chronicle, for example, bude, ide, načne, poteče, stvori, sědi, xoče (cf. Nekrasov 1897: 158). Ukrainian agrees with R3, while a number of dialects have 3rd sg. $-\mathrm{T} / \emptyset$ for $i$-verbs, for example nósy next to horýt' (Lomtev 1961: 263). In $e$-verbs, the zero ending must be old in this language because the thematic vowel did not become $i$, as would have been the case if the final syllable were closed. The large majority of East Slavic dialects have either a hard or a soft dental stop in both sg. and pl. endings, but the exceptions are particularly revealing. In the Onega area, some of the dialects have a soft dental stop in the $3 \mathrm{rd}$ pl. ending of the $e$-flexion $-u t^{\prime}$, but a hard dental stop in the other forms (e.g. Kuznecov 1956: 177). Since these dialects belong to R5, the hard dental is optional while the soft one is obligatory. They undoubtedly reflect an archaic distribution. 
Combining the Old Bulgarian and Russian dialectal evidence, we arrive at the following reconstruction of the Proto-Slavic system:

$\begin{array}{lllll} & e \text {-flexion } & i \text {-flexion } & \text { athematic } & \text { copula } \\ \text { 3rd sg. } & -e(t b) & -i t b & -t b & \text { jestb } \\ \text { 3rd pl. } & -e t b & -\ell(t b) & -e ̨ t b & \text { sqtb }\end{array}$

The athematic $3 r$ sg. ending can now be identified with PIE *-ti, and the ending of the $e$-flexion with the PIE thematic ending $*_{-} e$, which is also found in Baltic, Celtic, Greek, and Tocharian. ${ }^{18}$ The ending $-t z$ is of pronominal origin, as Fortunatov first suggested (1908). It is also attested in the 2 nd and $3 \mathrm{rd} \mathrm{sg}$. forms of root aorists which have a mobile stress pattern. This confirms that its distribution was determined by an interplay of accentual, morphological, and syntactical factors. From the accentological point of view, the addition of $-t b$ restored the accentuability of barytone forms of oxytone paradigms after they had become unstressed in Slavic (cf. Kortlandt 1978a: 75). Morphologically, it could serve to eliminate homonymy between present and aorist forms. Since the thematic aorist properly belongs to barytone paradigms in Slavic (Dybo 1961) while oxytona were particularly frequent among the underived $e$-verbs, the generalization of present nesetb and aorist nese in Old Bulgarian is not

${ }^{18}$ On Tocharian cf. Pedersen 1941: 142f. The Greek ending -ei is best explained as PIE * $e$ with an additional $i$ from the athematic flexion (cf. Chantraine 1967: 297). The motivation for the enlargement can be found in the obliteration of the distinction between primary and secondary endings as a result of the loss of final $* t$. The Celtic facts are complicated. In order to derive all desinences from PIE primary endings, Cowgill posits an early loss of $*_{-i}$ in 3 rd sg. and pl. conjunct forms (1975: 57), but not in the corresponding absolute forms (1975: 59), and in the $3 \mathrm{rd} \mathrm{sg}$. relative form, but not in the $3 \mathrm{rd} \mathrm{pl.} \mathrm{relative} \mathrm{form} \mathrm{(ibidem).}$ Here I agree with Watkins that we have to start from an original 3rd sg. ending *-e and that the relative form beres replaces *bere, which regularly developed from *bere-io, on the analogy of the relative copula as (1969: 169). The 3rd sg. absolute form *bere-s took *-ti-from the athematic flexion, while the conjunct form remained unchanged. The reason for the different treatment of abs. and conj. forms must be sought in the shortening of long final vowels (=stage 4 of my footnote 15), which yielded the following paradigms (cf. Watkins 1969: 170f):

\begin{tabular}{|c|c|c|c|}
\hline 1st sg. abs. & $\begin{array}{l}\text { *bherelo- } \\
\text { berūh }\end{array}$ & $\begin{array}{l}\text { *rödeielo- } \\
\text { rādiüh }\end{array}$ & $\begin{array}{l}\text { *rudhe- } \\
\text { rudimih }\end{array}$ \\
\hline 2nd sg. abs. & berih & rädīih & rudiüh \\
\hline 3rd sg. abs. & bereh & rädieh & ruditih \\
\hline 1st sg. conj. & -beru & -rādĩu & -rudimi \\
\hline 2nd sg. conj. & -beri & $-r a ̈ d \ddot{i}$ & -rudïi \\
\hline 3rd sg. conj. & -bere & $-r \vec{a} d \bar{l}$ & -ruditti \\
\hline
\end{tabular}

At this stage, * rädieh was apparently replaced with * räditih, and *-ruditi with *-rudi. 
surprising. ${ }^{19}$ In the $i$-flexion, the accentological argument applies to causatives (Stang 1952a), denominatives from accentually mobile nouns (Van Wijk 1918), and old perfects, and the morphological argument to iteratives, causatives, and denominatives, while old athematic verbs had a $3 \mathrm{rd} \mathrm{sg}$. ending $*_{-}-t i$. The spread of $-t z$ to the $3 \mathrm{rd}$ pl. present and the $2 \mathrm{nd} \mathrm{sg}$. aorist forms is obviously secondary. Syntactically, there seems to be a preference for the ending $-\emptyset$ to be used in sentences with an indefinite subject, as Obnorskij argued (1953: 133ff). ${ }^{20}$ Fortunatov already pointed to the apparent identity of Slavic $-t z$ with Prussian $-t s$, which is an anaphoric subject marker, for example $(49,6)$ imma tans stan geitin dinkauts bhe limauts, bhe dai swaimans maldaisimans, bhe billats "Nam er das Brodt, dancket, vnnd brachs, vnnd gabs seinen Jüngern vnnd sprach". ${ }^{21}$ Since Slavic $-t z$ represents the nominative-accusative which continues PIE *tom, not *tos, the identity is not complete. I think that Watkins correctly conjectures that "beide unabhängig ein früheres Pronomen *os ersetzt haben, das mit dem heth. Suffixpronomen -ăs, -at zusammenstimmte" (1969: 219) and which has a syntactic equivalent in Old Irish -som and Tocharian A $-s, \mathrm{~B}-m$. The PIE secondary ending *-et has been preserved as $-e$ in the Slavic thematic aorist. Its merger with the present ending *-e caused the loss of the distinction between primary and secondary endings in Baltic.

The Baltic athematic ending - $t i$ can be identified with PIE *-ti, while the thematic ending $-a$ and the semi-thematic ending $-i$ have apparently resulted from paradigmatic levelling: the $e$-grade which is found in Slavic $*_{-}^{*} e$ and $*_{-e i}$ was replaced with $o$-grade and zero grade, respectively. The generalization of the thematic vowel $a$ instead of $e$ in Baltic is no trivial development. I think that the key argument was presented by Schmalstieg in $1958 .{ }^{22}$ As a result of the merger of ${ }^{*} \mathrm{Cje}$ and ${ }^{*} \mathrm{Ce}$ in Baltic, the present stem suffixes $-e / 0$ - and $-j e / o$ - merged in those forms where the thematic

19 The establishment of the distribution in this category must apparently be dated to the period between the rise of the falling intonation (Kortlandt 1975a: xii, stage 10) and Dybo's law (ibidem, stage 17).

${ }^{20} \mathrm{I}$ infer from Panzer's footnote (1967: 297) that this point of view is perhaps supported by Karneeva-Petrulan's analysis in Narysy pa historyi belaruskaj movy (Minsk 1957), pp. $216 \mathrm{ff}$, which has not been accessible to me.

${ }^{21}$ Cf. also $(41,20)$ Beggi schläits Deiwas wirdan, ast stas vnds ains tickars vnds, bhe niainā Crixtisna, adder sen stesmu wirdan Deiwas, astits ainä Crixtisnā "Denn on Gottes wort, ist das wasser schlecht wasser, vnd kein tauff, aber mit dem wort Gottes ists ein tauffe".

${ }^{22}$ I cannot follow Schmalstieg in the later modifications of his view because I think that the rise of the palatalization correlation in Baltic and Slavic is recent and did not reach Serbo-Croat, Slovene, Old Prussian, Žemaitian, and the majority of Latvian dialects. 
vowel was $e$. The morphophonological reinterpretation of the ambiguous forms as belonging to the je/o-paradigm led to the generalization of the back vowel in the $e / o$-paradigm. The subsequent restoration of $* j$ in the je/o-flexion implied the introduction of the reflex of * $o$, which had become an archiphoneme in the position after $* j$ as a result of the loss of $* j$ in $* C j e$. There is additional evidence for this point of view in the frequent correspondence of je/o-verbs in Baltic with e/o-verbs in Slavic (cf. Stang 1942: 122), for example Lith. baũdžia, Ru. bljudët, Skt. bódhati. Slavic retained the old distribution of $*_{e}$ and $*_{o}$ in the thematic vowel because the $*_{j}$ in ${ }^{*} C j e$ coalesced with the preceding consonant in this language, not with the following vowel. ${ }^{23}$

\section{The 1st pl. ending}

Baltic presents PIE *-me in Lith. -me and PIE *-mo in Prussian -mai (with an analogical $-i$ from the sg. endings). The acute intonation which the East Baltic reflexive forms indicate was apparently taken from the singular, or represents an analogical $*_{-} H$ (which amounts to the same thing). The Slavic facts are complicated. Four endings are attested all over the Slavic territory: $-m z$ in Old and Modern Bulgarian, Russian, Old and dialectal Polish, Old and dialectal Czech, West Slovak, and Old Slovene (FF), -mo in Serbo-Croat, Slovene, Central Slovak, and Ukrainian, -me in Bulgarian, Macedonian, Czech, Slovak, and Old Russian (Novgorod), and $-m y$ in Old (Suprasliensis) and Middle Bulgarian, Old Russian, Polish, Sorabian, and Old Czech. The latter ending arose under the influence of the pronoun $m y$. The origin of -me is heterogeneous. In Middle Bulgarian, the expansion of -me and $-m y$ is closely connected with the spread of the new 1st sg. ending $-m$ (cf. Lekov 1934: 128f). The vowel of -me was apparently taken from the $2 \mathrm{nd} \mathrm{pl}$. ending -te in order to avoid the homonymy of the $1 \mathrm{st}$ sg. and pl. endings. This argument does not apply to the West Macedonian dialects of the Debar area, where the generalization of -me in the absence of a 1st sg. ending $-m$ points to an older source (cf. Oblak 1896:110). In Old Czech, the ending -me is frequent in the aorist, where any influence of the $1 \mathrm{st} \mathrm{sg}$. form is excluded, for example vedechme (next to the present form vedem, 1st sg. vedu), conditional abychme and bychome. It is therefore probable that it continues an athematic secondary ending *-me. The Ukrainian evidence suggests that the ending $-m o$, which is the expected

\footnotetext{
${ }^{23}$ The Slavic umlaut of the thematic vowel in $1 \mathrm{st} \mathrm{pl}$. znajem evoked its analogical replacement in dvignemb, but not in the aorist dvigomb, where the model was lacking.
} 
reflex of PIE *-mo and *-mos, belongs originally to the athematic present flexion. The ending $-m b$, which points to PIE *-mom, is apparently the Proto-Slavic thematic ending.

The hypothesis that Slavic $-m z,-m o$, and $-m e$ partly reflect the original PIE distribution is compatible with the evidence from the other languages. Greek -mes represents the primary athematic ending *-mes, while -men may be a contamination of the primary thematic ending *-mom with the secondary athematic ending *-me. Latin -mus continues a primary ending *-mos, which looks like a contamination of the thematic ending *-mom

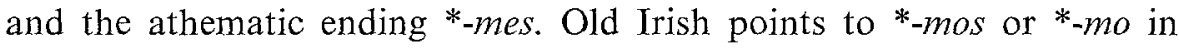
conj. -beram, ${ }^{*}$-mos-io in rel. bermae, ${ }_{-m}$ mo in the negative copula nidan (leniting). The absolute form bermai cannot represent *-mos-es because of the passive preterit brethae from *-os-es (cf. Cowgill 1975: 60). I think that it received its final $-i$ on the analogy of $3 \mathrm{rd}$ pl. berait, cf. the corresponding conjunct forms, -beram, -berat. ${ }^{24}$ As in Italic and Celtic, the primary athematic ending *-mes was apparently replaced with *-mos at an early stage in Slavic. This substitution must have been anterior to the raising of *o to $* u$ in the thematic ending *-mom.

\section{The 2nd pl. ending}

The PIE endings *-tHe and *-te merged phonetically everywhere outside Indo-Iranian. They are represented in Lith. -te and Slavic -te. The distribution of the three Prussian endings -ti, -tei $(-t e)$, and -tai has been clarified by Stang $(1966: 418 f)$. As a rule, the forms in -tai are athematic and the forms in -tei (-te) are imperatives. The normal ending -ti points to $*_{\text {-te } H}$, with an analogical $*_{-} H$ from the singular endings of the thematic flexion, which is also indicated by the East Baltic reflexive forms. The ending -tei contains an additional $-i$ which is also attested in the 2 nd sg. ending *-eHi and which must perhaps be derived from a PIE reinforcing particle (cf. Safarewicz 1963: 111). The ending -tai arose on the analogy of the $2 \mathrm{nd} \mathrm{sg}$. and $1 \mathrm{st} \mathrm{pl}$. endings in -ai.

\section{The 3rd pl. ending}

I cannot share the common view that the $3 \mathrm{rd}$ pl. ending was lost in Baltic. If the $n t$-endings once had the same extension here as in the other

${ }^{24}$ This analogical change must be dated between stage 4 and stage 7 of my footnote 15 . It did not affect the 2 nd pl. form *beretêh, which developed from *beretes-es. 
Indo-European languages, their disappearance would be totally unmotivated. Endzelin attributes the loss of ${ }^{*}-n t$ to the homonymy of the indicative and the relative mood (1922: 551). I fail to see how such homonymy could have led to the elimination of the original indicative ending. One would rather expect either a syntactic innovation or a replacement of the relative ending with the nom. pl. form of the participle. Moreover, there is no indication that the homonymy ever arose. The Slavic evidence points to a thematic $3 \mathrm{rd}$ pl. ending *-onti next to the $3 \mathrm{rd}$ sg. ending $*_{-} e$ and an athematic 3rd pl. ending *-(e)nti next to the $3 \mathrm{rd} \mathrm{sg}$. ending *-ti. There is no reason to assume a secondary ending ${ }^{*}$-ont in the present tense of the thematic paradigm. I conclude that the Baltic evidence points to a $3 \mathrm{rd} \mathrm{pl}$. ending ${ }^{*}-o$ and that this ending may be very old. ${ }^{25}$

From the Indo-European point of view, the $n t$-endings belong to the same set as the $m / s / t$-endings of the singular and should not be expected to occur in the thematic present, where the singular endings were $-o H,-e H i$, $-e$. The analogical introduction of the athematic endings in Skt. 2nd sg. bhárasi, 3rd sg. bhárati and Gothic bairis, bairip deprive the corresponding 3rd pl. forms bháranti, bairand of any value for the reconstruction of the PIE thematic ending. The Latin endings -it and -unt cannot be derived from *-eti and *-onti because a final $-i$ is not lost, cf. mare, loc. pede, inf. amāre. I think that we must start from the original thematic endings $*_{-} e$ and $*_{-}-$, which were enlarged by ${ }^{*}-t$ and ${ }^{*}-n t$ after the loss of the distinction between primary and secondary endings in this language. ${ }^{26}$ Similarly, Old Irish 3 rd pl. conj. -berat must be derived from *bhero and secondary * $n t$, while the absolute form berait represents the same form with *-nti from the athematic flexion before the enclitic ${ }^{*}{ }_{-S .}{ }^{27}$ Greek and Slavic added ${ }^{*}-n t i$ from the athematic flexion to the primary ending *-o on the analogy of the secondary endings. In the $i$-flexion, the Slavic present ending *-ę(tz) still testifies to the original absence of $*_{-n t i}$ : the generalization of the perfect ending *-ent, which had replaced the original $r$-ending at an early stage, was apparently anterior to the rise of $*_{\text {-onti }}$ in the thematic flexion.

\footnotetext{
${ }^{25}$ Endzelin's suggestion that the original $3 \mathrm{rd}$ pl. form was preserved in such instances as Lith. nebeturim kas valgq "wir haben nichts mehr zum Essen", jis žinos kas darq "er wird wissen, was zu machen ist" $(1913: 125)$ cannot be maintained in view of the nominative kas, The form in $-a$ represents the neuter of the participle, which has preserved its original passive meaning with transitive verbs, as in Hittite.

${ }^{26}$ Likewise, the 2 nd sg. ending -is cannot represent *-esi: it must be explained along the same lines.

${ }^{27} \mathrm{Cf}$. my footnote 18 . The differentiation between abs. and conj. forms is analogous to the development in the singular and must be dated to the same stage.
} 
Finally, the $3 \mathrm{rd}$ pl. ending *-o has been preserved in Tocharian B, where 3rd sg. ásäm and 3rd pl. äkem are identical with PIE *Haĝe and ${ }^{*} H a \hat{g} o$ plus an enclitic element. Tocharian A added ${ }^{*}-n t i$ in the plural form, e.g. $\bar{a} k e \tilde{n} c$, but preserved the old ending in a number of cases, especially before the 1st sg. suffixed pronoun -ñi, e.g. tsäkseñi, tākeñi (cf. Sieg et al. 1931: 326ff). The forms in $-e$ are frequent in the Maitreyāvadānavyākarana, which is archaic for palaeographic reasons. ${ }^{28}$ The PIE secondary endings are attested in the Slavic aorist, thematic $-\varphi$ from *-ont, athematic $-\varepsilon$ from *-ent.

\section{A note on the PIE verbal system}

Though a full analysis of the PIE verbal system goes beyond the scope of this contribution, it seems useful to add a short comment on the reconstruction of the earlier stages, especially because I think that some of the recent work in this area suffers from an undesirable methodological bias. It is a common truth that much of the development of language can be attributed to the generalization of rules. If this is correct, one cannot hope to reconstruct a proto-system through the generalization of rules which are attested in the daughter languages. In his stimulating monograph on the history of the Indo-European verbal flexion, Watkins rejects the usual interpretation of the 1st sg. ending in Gr. ágo and Lat. agō as PIE ${ }^{*} o H$ for two reasons (1969: 109). On the one hand, Watkins sees no relation between this reconstruction and comparable paradigms or other endings of the same paradigm. I would rather consider this an argument for the antiquity of the ending * $o H$. On the other hand, Watkins regards the vowel colourings of *-Ho in Gr. $-a$ and ${ }^{*}-o H$ in Gr. $-\bar{o}$ as incompatible. This statement rests upon three unproven premisses. First, the laryngeal of the perfect ending is not necessarily identical to the one in the thematic present. Second, the vowel of the perfect ending may represent $*_{-} e$ rather than $*_{-} o$. Third, there are weighty arguments both for Gr. $a$ as the reflex of ${ }^{*} \mathrm{H}_{2} \mathrm{O}$ (e.g. agós, cf. trophós) and for Gr. $\bar{o}$ as the reflex of ${ }^{*} \mathrm{H}_{2}$ (e.g. phônế, cf. poinế). As long as this problem has not reached its final solution, there is no reason to exclude the possibility that the differing colourings are compatible. Incidentally, the acute intonation of Lith. - ì leaves no doubt

${ }^{28}$ Unlike the other Toch. A manuscripts, the Maitreyāvadānavyākaraṇa still uses the $s \ddot{a}-$ doublet, which was apparently eliminated in the other texts because of its resemblance with the șä-doublet and the ya-sign (cf. Pedersen 1941: 19). It writes krañc and läñ for krams and läms, also krañcän for krañcäm, and often $i, \bar{u}$ for $i, u$ (cf. Sieg et al. 1921: viii). 
about the correctness of the reconstruction * ${ }^{*} \mathrm{oH}$. Another instance of incorrect generalization on the basis of more recent patterns is found in Neu's reconstruction of the PIE perfect (1968: 154f and 1976: 248f). Neu posits an original set of perfect endings $*_{-} H o, *_{-}$tho, ${ }_{-} o$, which subsequently split into a present set ${ }^{*}-H a, *_{-}^{*} t h a, *_{-a} a$ and a preterit set ${ }^{*}-H o$, *-tho, ${ }^{*}-o$. The rise of the new vowel quality not only remains unexplained, but in turn does not explain the Greek 3rd sg. ending $-e$, which must be old in view of Old Irish - cechain. The standard theory which interprets the 1 st sg. ending as $*_{-} \mathrm{H}_{2} e$ is certainly preferable.

A strict comparative analysis of the material yields at least the following sets of PIE verbal endings:

$\begin{array}{lllllll} & \mathrm{I} & \mathrm{II} & \mathrm{III} & \mathrm{IV} & \mathrm{V} & \mathrm{VI} \\ \text { 1st sg. } & -m i & -m & -o m & -o H & -H a & -\mathrm{H}_{2} \\ \text { 2nd sg. } & -s i & -s & -e s & -e H i & -t H a & -t H o \\ \text { 3rd sg. } & -t i & -t & -e t & -e & -e & -o \\ \text { 1st pl. } & -m e s & -m e & -o m o & -o m o m & -m e & -m e d h H_{2} \\ \text { 2nd pl. } & -t H e & -t e & -e t e & -e t H e & -e & - \text { dhue } \\ \text { 3rd pl. } & -(e) n t i & -(e) n t & -o n t & -o & -(\bar{e}) r & -r o\end{array}$

The addition of the final $-i$ from set $\mathrm{I}$ to the endings of set $\mathrm{V}$ yielded the Latin perfect and the Hittite $h i$-present, whereas its addition to the endings of set VI produced the ai-medium of Greek and Indo-Iranian. It appears that the endings of set II (active) could be enlarged by the corresponding endings of set VI (stative) in order to supply a medial paradigm in the proto-language. ${ }^{29}$ The system looks like the remains of a much more elaborate structure. Writing '? for morpheme boundaries between suffixes and ' $:$ ' for morpheme boundaries within suffixes, I would suggest the following internal reconstruction:

$\begin{array}{lllllll} & \mathrm{I} & \mathrm{II} & \mathrm{III} & \text { IV } & \mathrm{V} & \text { VI } \\ \text { 1st sg. } & -m . i & -m & -o . m & -o . H_{1} & -\emptyset . H_{2} . e & -\emptyset . H_{2} \\ \text { 2nd sg. } & -s . i & -s & -e . s & -e . H_{1} . i & -t . H_{2} . e & -t . H_{2} . o \\ \text { 3rd sg. } & -t . i & -t & -e . t & -e & -e & -o \\ \text { 1st pl. } & -m e \cdot s & -m e & -o . m o & -o . m o: m & -m e & -m e: d h . H_{2} \\ \text { 2nd pl. } & -t . H_{1} e & -t e & -e . t e & -e . t . H_{1} e & -\emptyset . e & -\emptyset: d h . u e \\ \text { 3rd pl. } & -n t . i & -n t & -o . n t & -o & -r & -r . o\end{array}$

The exact meaning of the separate morphemes can no longer be established. As Pedersen pointed out already (1938: $84 \mathrm{f})$, the $\mathrm{m} / \mathrm{s} / \mathrm{t}$-endings seem to

${ }^{29}$ If this is correct, the Greek. 2nd pl. medial ending -sthe can be derived from *-t.dhue, and the 1 st $\mathrm{pl}$. ending -mestha next to -metha may have taken its $-s$-either from the primary active ending -mes next to secondary ${ }^{*}-m e$ or from the 2 nd pl. medial ending -sthe next to stative *-the. 
belong originally to the flexion of dynamic verbs. In the other flexion types, we find different sets of endings. The $r$-morpheme is perhaps the reffex of an indefinite plural subject marker, whereas the exact function of $H_{1}$ in the thematic present and $\mathrm{H}_{2}$ in the perfect and the stative is unclear to me (dative markers?). I think that Knobloch's suggestion about the origin of the thematic vowel (1953) is essentially correct and that -e/o- goes back to a definite object marker (cf. Pedersen 1933: 321ff on the resemblance with the Samoyed verbal system). Thus, the difference between Skt. ád-mi and Gr. éd-o.m.ai is typologically comparable to the one between Bulg. $s p j-a$ 'I sleep' and spi-Ø mi se 'I am sleepy'. It is clear from this example that the thematic flexion need not have been limited to transitive verbs. The tentative analysis outlined here leads to a sequence of seven partly compatible sets of mutually exclusive suffixes:

(1) Definite object marker $-e / o$ -

(2) Agent marker: 1st sg. - $m$, 2nd sg. $-s$, 3rd sg. $-t, 1$ st pl. - $-m e(s), 2$ nd pl. $-t(e), 3 \mathrm{rd}$ pl. $-(e) n t$.

(3) Indirect object marker: 1st sg. - - -, $^{2}$ 2nd sg. -t-, 1st pl. -me(dh)-, 2nd pl. $-\emptyset(d h)$ -

(4) Indefinite plural subject marker -r.

(5) Laryngeal in nondynamic verb forms (not in the $3 \mathrm{rd}$ person): $-H_{1^{-}}$- in the thematic present, $-H_{2}$ - in the perfect and the stative. ${ }^{30}$

(6) Voice marker: $-e$ in the perfect, $-o$ in the stative.

(7) Tense marker $-i$ in the present.

The compatibility of the suffixes may have been different in the various dialectal areas.

${ }^{30}$ We may posit 1st pl. thematic present $-o m H_{1} o m$, perfect $-m H_{2} e, 2$ nd pl. perfect $-H_{2} e$, stative $-d h H_{2} u e$, but this analysis is not supported by the available evidence.

\section{References}

Boling, B.D., 1972. Some problems of the phonology and morphology of the Old Irish verb. Eriu 23, 73-101.

Brugmann, K., 1904. Zur Bildung der 2. Person Singul. Akt. in den indogermanischen, insbesondere den baltischen Sprachen. Indogermanische Forschungen 17, 177-186.

Chantraine, P., 1967. Morphologie historique du grec. Paris.

Cowgill, W., 1975. The origins of the insular Celtic conjunct and absolute verbal endings. Flexion und Wortbildung, 40-70. Wiesbaden.

Dybo, V.A., 1961. Udarenie slavjanskogo glagola i formy staroslavjanskogo aorista. Kratkie soobščenija Instituta slavjanovedenija 30, 33-38.

Endzelin, J., 1913. Miszellen. Indogermanische Forschungen 33, 119-127.

Endzelin, J., 1922. Lettische Grammatik. Riga. 
Fortunatov, F.F., 1908. Staroslavjanskoe $-t z$ v 3-m licě glagolov. Izvěstija Otdělenija russkago jazyka i slovesnosti 13/2, 1-44.

Jurišić, B., 1966. Rječnik govora otoka Vrgade I: Uvod. Zagreb.

Knobloch, J., 1953. La voyelle thématique -e/o-serait-elle un indice d'objet indo-européen? Lingua 3, 407-420.

Kortlandt, F.H.H., 1974. Old Prussian accentuation. Zeitschrift für vergleichende Sprachforschung 88, 299-306.

Kortlandt, F.H.H., 1975a. Slavic accentuation: A study in relative chronology. Lisse: The Peter de Ridder Press.

Kortlandt, F.H.H., 1975b. Jers and nasal vowels in the Freising Fragments. Slavistična Revija 23, 405-412.

Kortlandt, F.H.H., 1978a. A history of Slavic accentuation. Lingua 44, 67-91.

Kortlandt, F.H.H., 1978b. On the history of the genitive plural in Slavic, Baltic, Germanic, and Indo-European. Lingua 45, 281-300.

Kuryłowicz, J., 1964. The inflectional categories of Indo-European. Heidelberg.

Kuznecov, P.S., 1956. K istorii form 3-go lica nastojaščego vremeni glagola $\mathrm{v}$ russkom jazyke. Slavia 25, 175-183.

Kuznecov, P.S., 1960. Russkaja dialektologija. Moskva.

Kuznecov, P.S., 1961. Očerki po morfologii praslavjanskogo jazyka. Moskva.

Lekov, I., 1934. Praslavjanskitě glagolni formi i otraženijata im v dnešnitě slavjanski ezici. Spisanie na Brlgarskata Akademija na Naukitě 24/50, 1-196.

Lomtev, T.P., 1961. Sravnitel'no-istoričeskaja grammatika vostočnoslavjanskix jazykov: Morfologija. Moskva.

Mareš, F.V., 1962. The Slavic verbal forms of the 3rd person plural bede and bo. International Journal of Slavic Linguistics and Poetics 5, 28-30.

Meillet, A., 1908. A propos de v.irl. beri. Mémoires de la Société de Linguistique de Paris 14, 412-415.

Meillet, A., 1922. Remarques sur les désinences verbales de l'indo-européen. Bulletin de la Société de Linguistique de Paris 23, 64-75.

Nekrasov, N.P., 1897. Zamětki o jazykě 'Pověsti vremennyx lět' po Lavrent'evskomu spisku lětopisi: Morfologičeskija zamětki. Izvěstija Otdělenija russkago jazyika $i$ slovesnosti $2 / 1,104-174$.

Neu, E., 1968. Das hethitische Mediopassiv und seine indogermanischen Grundlagen. Wiesbaden.

Neu, E., 1976. Zur Rekonstruktion des indogermanischen Verbalsystems. Studies in Greek, Italic, and Indo-European linguistics, 239-254. Innsbruck.

Oblak, V., 1893. Dat. und loc. sgl. njej-nji. Archiv für slavische Philologie 15, 468-470.

Oblak, V., 1896. Macedonische Studien. Sitzungsberichte der philosophisch-historischen Classe der Kaiserlichen Akademie der Wissenschaften 134/8. Wien.

Obnorskij, S.P., 1953. Očerki po morfologii russkogo glagola. Moskva.

Panzer, B., 1967. Der morphologische Umbau der slavischen Präsensflexion. Zeitschrift für slavische Philologie 33, 290-304.

Pedersen, H., 1933. Zur Frage nach der Urverwandtschaft des Indoeuropäischen mit dem Ugrofinnischen. Mémoires de la Société Finno-ougrienne 67, 308-325.

Pedersen, H., 1938. Hittitisch und die anderen indoeuropäischen Sprachen. København.

Pedersen, H., 1941. Tocharisch vom Gesichtspunkt der indoeuropaischen Sprachvergleichung. København.

Penney, J.H.W., 1978. The treatment of Indo-European vowels in Tocharian. Transactions of the Philological Society 1976-7, 66-91.

Ramovš, F., 1920. K zgodovini slovanske konjugacije. Časopis za slovenski jezik, književnost in zgodovino $2,128-130$. 
Rix, H., 1977. Das keltische Verbalsystem auf dem Hintergrund des indo-iranisch-griechischen Rekonstruktionsmodells. Indogermanisch und Keltisch, 132-158. Wiesbaden.

Safarewicz, J., 1963. Sur les désinences verbales en grec et en latin. Eos 53, 107-115.

Schmalstieg, W.R., 1958. The thematic vowel in Baltic. Lingua 7, 428-432.

Schmid, W.P., 1963. Studien zum baltischen und indogermanischen Verbum. Wiesbaden.

Schmid, W.P., 1969. Baltische Beiträge VI: Zu altpreussisch asmai 'ich bin'. Indogermanische Forschungen 73, 355-361.

Sieg, E., W. Siegling, 1921. Tocharische Sprachreste. Berlin.

Sieg, E., W. Siegling, W. Schulze, 1931. Tocharische Grammatik. Göttingen.

Stang, C.S., 1942. Das slavische und baltische Verbum. Oslo.

Stang, C.S., 1952a. Sur l'accentuation des verbes causatifs et itératifs en slave. Norsk Tidsskrift for Sprogvidenskap 16, 263-270.

Stang, C.S., 1952b. Eine Bemerkung zur slowakischen Präsensflexion. Norsk Tidsskrift for Sprogvidenskap 16, 271-275.

Stang, C.S., 1957. Slavonic accentuation. Oslo.

Stang, C.S., 1966. Vergleichende Grammatik der Baltischen Sprachen. Oslo.

Thurneysen, R., 1884. Der italokeltische conjunctiv mit $\hat{a}$. Beiträge zur kunde der indogermanischen sprachen $8,269-288$.

Trubeckoj, N., 1922. O někotoryx ostatkax isčeznuvšix grammatičeskix kategorij v obščeslavjanskom prajazykě. Slavia 1, 12-21.

Vaillant, A., 1930. L'impératif-optatif du slave. Slavia 9, 241-256.

Vaillant, A., 1966. Grammaire comparée des langues slaves III: Le verbe. Paris.

Watkins, C., 1969. Indogermanische Grammatik: Geschichte der indogermanischen Verbalflexion. Heidelberg.

Wiedemann, O., 1886. Beiträge zur altbulgarischen Conjugation. St. Petersburg.

Van Wijk, N., 1916. Zur slavischen und baltischen Präsensflexion. Archiv für slavische Philologie 36, 111-116.

Van Wijk, N., 1918. Zur Betonung der Verba mit stammbildendem i. Archiv für slavische Philologie 37, 1-46.

Van Wijk, N., 1927. Die sogenannten Verba iterativa und die Bezeichnung der wiederholten Handlung im Altkirchenslavischen. Indogermanische Forschungen 45, 93-104.

Van Wijk, N., 1929. Sur l'origine des aspects du verbe slave. Revue des études slaves 9 , 237-252.

Van Wijk, N., 1931. Geschichte der altkirchenslavischen Sprache I: Laut- und Formenlehre. Berlin.

Van Wijk, N., 1933. Le problème des prétérito-présents slaves et baltiques. Studi Baltici 3, 134-139.

Winter, W., 1978. The distribution of short and long vowels in stems of the type Lith. ësti: vèsti:mèsti and OCS jasti:vesti:mesti in Baltic and Slavic languages. Recent developments in historical phonology, 431-446. The Hague: Mouton.

Žgur, A., 1968. Uebersetzung ins Deutsche, Freisinger Denkmäler. Ed. J. Pogačnik, 219-221. München. 